\title{
Plant regeneration from embryogenic callus and cell suspensions of Brachiaria brizantha
}

\author{
Glaucia B. Cabral • Vera T. C. Carneiro • \\ Mônica L. Rossi • Joseane P. da Silva • \\ Adriana P. Martinelli • Diva M. A. Dusi
}

Received: 25 November 2013 / Accepted: 31 March 2015 / Published online: 19 May 2015 / Editor: Lynn Dahleen

(C) The Society for In Vitro Biology 2015

\section{Introduction}

In monocots, in vitro plant regeneration can be obtained through somatic embryogenesis (Vasil and Vasil 1980, 1982; Vasil 2005). Evidence of more than one morphogenic response in the same explant, under the control of different auxin/cytokinin ratios and concentrations, was observed in species of the Poaceae family such as sorghum (Sorghum bicolor, (L.) Moench.), minor millet (Paspalum scrobiculatum L.), sugar cane (Saccharum officinarum L.), and baby bamboo (Pogonatherum paniceum Lam. Hack.) (reviewed by Wang et al. 2008).

Brachiaria callus has been induced using seeds as explants from Brachiaria brizantha (Hochst. ex A. Rich.) Stapf, Brachiaria decumbens Stapf, Brachiaria ruziziensis Germain et Evrard and Brachiaria dictyoneura [Brachiaria humidicola (Rendle) Schweick vr. Lanero, ex B. dictyoneura] (Tohme et al. 1996). Subsequently, using the same methodology, calli were induced from $76 \%$ of isolated embryos from seeds of B. brizantha (Lenis-Manzano 1998). The formation of somatic embryos and multiple shoots from seedling apical meristems was demonstrated for B. ruziziensis (Ishigaki et al. 2009). In this system, mature seeds were used as source of explants and cultured on a medium containing $4 \mathrm{mg} / \mathrm{L}$ 2,4-dichlorophenoxyacetic acid (2,4-D). Ishigaki et al.

Electronic supplementary material The online version of this article (doi:10.1007/s11627-015-9690-0) contains supplementary material, which is available to authorized users.

G. B. Cabral $(\bowtie) \cdot$ V. T. C. Carneiro • J. P. da Silva • D. M. A. Dusi Embrapa Genetic Resources and Biotechnology, Brasília, Brazil e-mail: glaucia.cabral@embrapa.br

M. L. Rossi • A. P. Martinelli

University of São Paulo, Piracicaba, Brazil
(2012) reported that embryogenic calli were more suitable than shoot apex explants for genetic transformation of ruzigrass.

B. brizantha cv. Marandu is the most important and cultivated forage grass in Brazil. It is tolerant to spittlebugs (Homoptera: Cercopidae complex, mainly genera Deois and Zulia), an economically important pest for Brachiaria (Felismino et al. 2012). This cultivar is considered as the key forage in beef cattle production in Brazil. Breeding is hindered by its apomictic reproductive mode (the production of clones of the mother plant), which reduces the possibility of being used for hybridizations (Valle and Savidan 1996). Alternatives to conventional breeding of $B$. brizantha would include genetic modification via transformation. However, methods of transformation and tissue culture of these plants are not yet established.

The development of embryogenic calli has been reported from $73 \%$ of the B. brizantha $\mathrm{cv}$. Marandu isolated seed embryos in culture and $67 \%$ of calli regenerated plants (Silveira et al. 2003). More recently, the histology of embryos isolated from the in vitro cultivated seed was shown (Lenis-Manzano et al. 2010). The formation of multiple shoots was reported in cultured basal segments from micropropagated plantlets of this cultivar (Pinheiro et al. 2000), a system that was efficient for in vitro chromosome duplication in Brachiaria. Somatic embryogenesis and organogenesis in B. brizantha is influenced by several factors such as genotype, explant type, and culture conditions (Cabral et al. 2011).

A high rate of cell division in explants used for genetic transformation of monocots is a prerequisite for the integration of exogenous DNA (Hiei et al. 1997; Vasil 2005). Rapid cell proliferation is a characteristic of embryogenic tissue. Cell suspension cultures (CS) are well known for their cell division capacity and the possibility of developmental-stage 
synchronization. This study describes the development and characterization of $B$. brizantha somatic embryogenesis from embryogenic callus and cell suspension cultures.

\section{Material and Methods}

Plant material. Seeds of the apomictic genotype B. brizantha (Syn. Urochloa brizantha) cv. Marandu (Embrapa's collection number BRA 000591) were kindly provided by Embrapa Beef Cattle, MS, Brazil.

Callus induction. Mature seeds were peeled and disinfested in a $70 \%$ ethanol solution for $5 \mathrm{~min}$, followed by $30 \mathrm{~min}$ in a $2.5 \%$ sodium hypochlorite solution with $0.1 \%$ Tween 20 , followed by five rinses in sterile distilled water. Three to 400 seeds were inoculated in Petri dishes (12 seeds per plate) containing one of the following induction media: $\mathrm{M} 1.3 \mathrm{pH} 4$, NB $\mathrm{pH} 5.8$, or NBBAP either at $\mathrm{pH} 4$ or $\mathrm{pH} 5.8$ (Table 1). The cultures were kept in the dark at $25 \pm 2{ }^{\circ} \mathrm{C}$ for $4 \mathrm{wk}$. After this period, embryogenic calli were identified and isolated, with the aid of a stereomicroscope, and transferred to fresh medium with the same composition, 30 to 50 pieces of embryogenic tissue per plate. The remaining calli were transferred to regeneration medium, half onto MS3 $\mathrm{pH} 4$ and the other half onto NBreg pH 5.8 (Table 1). After $10 \mathrm{~d}$, half of the calli were transferred to pre-regeneration medium ( $\mathrm{PRM} \mathrm{pH} \mathrm{5.8,} \mathrm{Table} \mathrm{1)}$ for 8 to $10 \mathrm{~d}$, and then transferred to regeneration medium, either MS3 or NBreg, while the other half was transferred directly to regeneration medium (MS3 or NBreg) (Table 1).

Callus induction for obtaining embryogenic cell suspension. Calli obtained on each solid induction medium, M1.3 pH 4 or NBBAP at $\mathrm{pH} 4$ or $\mathrm{pH} 5.8$, were subcultured to fresh medium, and after $15 \mathrm{~d}$ were transferred to liquid medium with the same composition. In each $250-\mathrm{mL}$ Erlenmeyer flask, containing $30 \mathrm{~mL}$ of medium, 10 to 15 calli were inoculated and maintained under agitation on an orbital shaker at $100 \mathrm{rpm}$ in the dark. Calli were cultured for 3 to $4 \mathrm{wk}$ for cell suspension (CS) proliferation, with weekly renewal of the medium accomplished by allowing cells to settle for a few minutes before pipetting the old medium out and adding new medium. After this period, the calli and differentiated embryos were removed by sedimentation. In a second sedimentation step, the settled cell volume (SCV) was measured using a conic centrifuge tube (Falcon $50 \mathrm{~mL}$ ).

To evaluate multiplication and regeneration, the CS was then divided into three parts. One part was maintained under agitation, for additional cell suspension proliferation and confirmation of embryogenic capacity. A second part was transferred to pre-regeneration medium and subsequently to regeneration medium, 200 to $300 \mathrm{mg}$ or $1 \mathrm{~mL} \mathrm{SCV}$, to confirm the ability of the cell aggregates to differentiate into embryos and/ or shoots. Pre-regeneration was carried out either in DD1 or PRM (Table 1) liquid medium at $\mathrm{pH} 5.8$, under agitation, for $1 \mathrm{wk}$ in the dark, followed by subculture to regeneration medium, either NBreg pH 5.8 or MS3 pH 4, solidified with Phytagel $^{\mathrm{TM}}$ and agar, respectively. The cell aggregates were cultivated for $3 \mathrm{~d}$ under moderate light (around $30 \mu \mathrm{mol} / \mathrm{m}^{2} /$ $\mathrm{s})$, and thereafter transferred to higher light conditions $\left(75 \mu \mathrm{mol} / \mathrm{m}^{2} / \mathrm{s}\right)$, both at a $16-\mathrm{h}$ photoperiod. The third part of the CS was cultured directly onto solidified regeneration medium, for 3 to $4 \mathrm{wk}$, with liquid regeneration medium (MS3) being added after $2 \mathrm{wk}$ to renew the medium components without subculture, to avoid contamination. All cultures were maintained at $25 \pm 2{ }^{\circ} \mathrm{C}$. Regenerated shoots were transferred to test tubes for elongation and rooting in MMP medium (Table 1). After $1 \mathrm{mo}$, the plantlets were acclimatized in the greenhouse, initially in vermiculite, and subsequently transferred to soil.

Statistical analyses. The free access R statistical program (R Core Team 2013) was used for all analyses, using an error rate of $p<0.05$. The effect of different culture media on morphogenesis was compared using the binomial model (ratio) or Poisson model (count or score). To correct the high variability (overdispersion) present in the data, the Quasi-likelihood method was used for estimating the heterogeneity factor.

The effect of $\mathrm{pH}$ in the somatic embryogenesis induction medium and the effect of two induction media in the observation times were compared by two-way ANOVA. The post hoc Tukey HSD multiple comparison test was conducted to access differences in settled cell volume (SCV) and observation times. The quality of the adopted model was measured by graphical analysis of the residues, as well as through tests of normality (Shapiro-Wilk test) and homoscedasticity of variances (Bartlett test).

The growth of $B$. brizantha cells in suspension culture was measured by the increase of SCV and was analyzed by the logistic curve. The logistic curve describes the changes in the volume increase $(Y)$ with respect to the culture time $(t)$, represented by the equation $Y_{t}=A\left(1+b e^{-k t}\right)^{-1}$. The parameters of this function are as follows: $A$ represents the stationary phase, $b$ is the scale parameter (constant), and $k$ represents the growth rate. The inflection point (change curve) occurs in $(b / k, \mathrm{~A} / 2)$. The fitness of the model was measured by the $R^{2}$ statistics. The plateau point was estimated using the segmented regression model.

Light and scanning electron microscopy. Embryogenic calli were collected at different developmental stages and processed for light microscopy (LM) and scanning electron microscopy (SEM). For LM, samples were fixed in paraformaldehyde $(4 \% v / v)$, dehydrated in an ethanol series (30 to $100 \%)$ at 30-min intervals, followed by propanol $(100 \%)$ for $8 \mathrm{~h}$, and then butanol (100\%) overnight. Infiltration was done at $4{ }^{\circ} \mathrm{C}$ 
Table 1 Media used for in vitro culture of Brachiaria brizantha in the present work

\begin{tabular}{|c|c|c|c|}
\hline Embryogenesis step & Medium and $\mathrm{pH}$ & Culture medium composition & References \\
\hline \multirow[t]{3}{*}{ Induction } & M1.3 pH 4.0 & $\begin{array}{l}\text { MS basal medium, } 300 \mathrm{mg} / \mathrm{L} \text { casein hydrolysate, } \\
3 \mathrm{mg} / \mathrm{L} 2,4-\mathrm{D}, 0.2 \mathrm{mg} / \mathrm{L} \mathrm{BAP}\end{array}$ & Cabral et al. (2011) \\
\hline & NB pH 5.8 & $\begin{array}{l}\text { N6 major salts, B5 minor salts and vitamins, } 100 \\
\mathrm{mg} / \mathrm{L} \text { Inositol, } 500 \mathrm{mg} / \mathrm{L} \text { proline, } 500 \mathrm{mg} / \mathrm{L} \\
\text { glutamine, } 300 \mathrm{mg} / \mathrm{L} \text { casein hydrolysate, } \\
2.5 \mathrm{mg} / \mathrm{L} 2,4-\mathrm{D}, 3 \% \text { sucrose, } 0.3 \% \text { Phytagel }\end{array}$ & Sallaud et al. (2003) \\
\hline & NBBAP pH 4.0 or 5.8 & NB medium supplemented with $0.2 \mathrm{mg} / \mathrm{L} \mathrm{BAP}$ & - \\
\hline \multirow[t]{2}{*}{ Pre-regeneration } & PRM pH 5.8 & $\begin{array}{l}\text { NB medium supplemented with } 5 \mathrm{mg} / \mathrm{L} \\
\mathrm{BAP}, 1 \mathrm{mg} / \mathrm{L} \text { NAA, } 2 \mathrm{mg} / \mathrm{L} \mathrm{ABA}, \\
0.7 \% \text { agarose type I }\end{array}$ & Sallaud et al. (2003) \\
\hline & DD1 pH 5.8 & $\begin{array}{l}\text { MS basal medium, } 10 \mathrm{mg} / \mathrm{L} \text { ascorbic acid, } \\
1.1 \mathrm{mg} / \mathrm{L} 2,4-\mathrm{D}, 0.2 \mathrm{mg} / \mathrm{L} \text { zeatin, } 3 \% \text { sucrose }\end{array}$ & Matsumoto (2006) \\
\hline \multirow[t]{2}{*}{ Regeneration } & MS3 pH 4.0 & $\begin{array}{l}\text { MS basal medium, } 300 \mathrm{mg} / \mathrm{L} \text { casein } \\
\text { hydrolysate, } 0.5 \mathrm{mg} / \mathrm{L} \mathrm{NAA}, 1 \mathrm{mg} / \mathrm{L} \\
\text { BAP, } 2.5 \mathrm{mg} / \mathrm{L} \text { kinetin }\end{array}$ & Cabral et al. (2011) \\
\hline & NBreg pH 5.8 & $\begin{array}{l}\text { NB medium supplemented with } 3 \mathrm{mg} / \mathrm{L} \\
\text { BAP, } 0.5 \mathrm{mg} / \mathrm{L} \text { NAA, } 0.6 \% \text { Phytagel }\end{array}$ & Sallaud et al. (2003) \\
\hline Elongation and rooting & MMP pH 5.8 & $\begin{array}{l}\text { MS basal medium, } 1 / 2 \text { strength major salts, } \\
100 \mathrm{mg} / \mathrm{L} \text { casein hydrolysate, } 0.5 \mathrm{mg} / \mathrm{L} \\
\text { kinetin, } 0.2 \mathrm{mg} / \mathrm{L} \mathrm{NAA}, 0.5 \mathrm{mg} / \mathrm{L} \mathrm{GA}_{3} \text {, } \\
2 \% \text { sucrose, } 0.7 \% \text { agar }\end{array}$ & Cabral et al. (2011) \\
\hline All media & $\begin{array}{l}\mathrm{pH} \text { was adjusted to } 5.8 \text { with } 1 \mathrm{~N} \mathrm{KOH} \\
\text { or to } 4.0 \text { with } 1 \mathrm{~N} \mathrm{HCl} \mathrm{prior} \mathrm{to} \mathrm{autoclaving.} \\
\text { Agar concentration was } 7 \mathrm{~g} / \mathrm{L} \text {, except for } \\
\mathrm{pH} 4 \text {, which was } 14 \mathrm{~g} / \mathrm{L} \text {. Medium was } \\
\text { autoclaved at } 121{ }^{\circ} \mathrm{C} \text { for } 20 \text { min. } \\
\text { When } \mathrm{ABA} \text { and } \mathrm{GA}_{3} \text { were supplemented } \\
\text { media were filter sterilized }\end{array}$ & & \\
\hline
\end{tabular}

$A B A$ abscisic acid; $B A P$ 6-benzylaminopurine; $G A 3$ gibberellic acid; $N A A$ naphthaleneacetic acid; 2,4-D 2,4-dichlorophenoxiacetic acid; $M S$ Murashige and Skoog (1962)

using butanol/infiltration medium (glycol methacrylate, Historesin kit (Leica, Heidelberg, Germany) (2:1, 1:1, 1:2, minimum of $2 \mathrm{~h}$ each step), followed by infiltration in $100 \%$ infiltration medium for $48 \mathrm{~h}$. Polymerization was done at room temperature for 24 to $48 \mathrm{~h}$. Histological serial sections (5- $\mu \mathrm{m}$ thick) were obtained in a rotary microtome (Leica RM 2155, Nussloch, Germany), stained with 0.05\% (w/v) toluidine blue in water, mounted in Entellan ${ }^{\circledR}$ synthetic resin (Merck, Darmstadt, Germany), covered with coverslips, and observed under an optical microscope Zeiss Axioskop 40 HBO 50 A/C (Carl Zeiss, Jena, Germany). For SEM, embryogenic units were fixed in paraformaldehyde $(4 \% v / v)$, dehydrated to $100 \%$ ethanol, critical point dried using liquid $\mathrm{CO}_{2}$, mounted on metal stubs, sputter coated with gold, and observed under a LEO 435 VP (Carl Zeiss, Jena, Germany) at $20 \mathrm{keV}$.

\section{Results and Discussion}

Embryogenic callus. Embryogenic calli were obtained after 3 to 4 wk of culture in M1.3 or NBBAP induction media. Seeds cultured in M1.3, with slightly higher 2,4-D concentration, showed significantly higher callus induction than those in NBBAP medium (Table 2, $p=0.0002$ ). In M1.3 medium, hyperhydric or watery non-embryogenic callus was not observed, contrasting with a frequency of $19 \%$ of this type of callus in NBBAP medium. Moreover, larger calli-with embryogenic callus, roots, and differentiated somatic embryos (DSE) - were formed in M1.3 medium at a frequency of $57 \%$, compared to $15 \%$ in NBBAP (Table 2, $p<2.2 \mathrm{e}-16$ ).

After removal of visible embryogenic callus from 2,4D/BAP-containing induction media (M1.3 or NBBAP), the remaining calli were plated onto regeneration medium (MS3 or NBReg), with cytokinin(s) only. Regardless of the induction medium, MS3 regeneration medium, produced a higher number of regenerants (Fig. 1). The combination of M1.3/MS3 media was the most efficient for shoot regeneration $(100 \%$; Fig. $1 A)$. These results are in accordance with previous observations showing high efficiency of the M1.3/MS3 media combination for inducing and regenerating plants via somatic embryogenesis in B. brizantha (Cabral et al. 2011). The profuse development of roots, regardless of the induction medium, was more frequent in NBreg than in MS3 medium (Fig. 1B). 
Table 2 Morphogenesis of Brachiaria brizantha cv. Marandu mature seeds cultivated on somatic embryogenesis induction media at $\mathrm{pH} 4$

\begin{tabular}{|c|c|c|c|c|c|}
\hline \multirow[t]{2}{*}{ Culture medium } & \multicolumn{2}{|c|}{ No. of seeds } & \multicolumn{3}{|l|}{ No. of calli } \\
\hline & Total & Without callus \pm SD & $\varnothing \leq 5 \mathrm{~mm}$, with roots and DSE & $\varnothing>5 \mathrm{~mm}$, with roots and DSE & Hyperhydric \\
\hline M1.3 & 400 & $38 \pm 5.6 \mathrm{~b}$ & $81 \pm 18.4 \mathrm{~b}$ & $227 \pm 20.8 \mathrm{a}$ & 0 \\
\hline NBBAP & 352 & $51 \pm 4.2 \mathrm{a}$ & $165 \pm 39.6 \mathrm{a}$ & $53 \pm 11 \mathrm{~b}$ & $68 \pm 14$ \\
\hline LR Chisq & - & 13.38 & 15.739 & 133.44 & \\
\hline$p$ value & - & 0.0002 & $7.27 \mathrm{e}-05$ & $<2.2 \mathrm{e}-16$ & \\
\hline
\end{tabular}

Data represent means $\pm \mathrm{SD}(n=3)$; Values followed by different letters in the same column are significantly different $(p<0.05)$

$L R$ likelihood ratio, DSE differentiated somatic embryos (with visible scutellum), $S D$ standard deviation, $\varnothing$ diameter

The high frequency of shoot development on MS3 medium could have been favored by a synergistic effect of the combination of the cytokinins kinetin $(2.5 \mathrm{mg} / \mathrm{L})$ and 6benzylaminopurine (BAP; $1 \mathrm{mg} / \mathrm{L}$ ). Similar behavior was observed in bud formation in Brachiaria spp. on micropropagation medium (Cabral et al. 2011). The induction/regeneration media combination NB/NBreg was originally used for rice somatic embryogenesis (Sallaud et al. 2003), and even though these media are richer in free amino acids than M1.3/MS3, the best response for $B$. brizantha was obtained with the M1.3/MS3
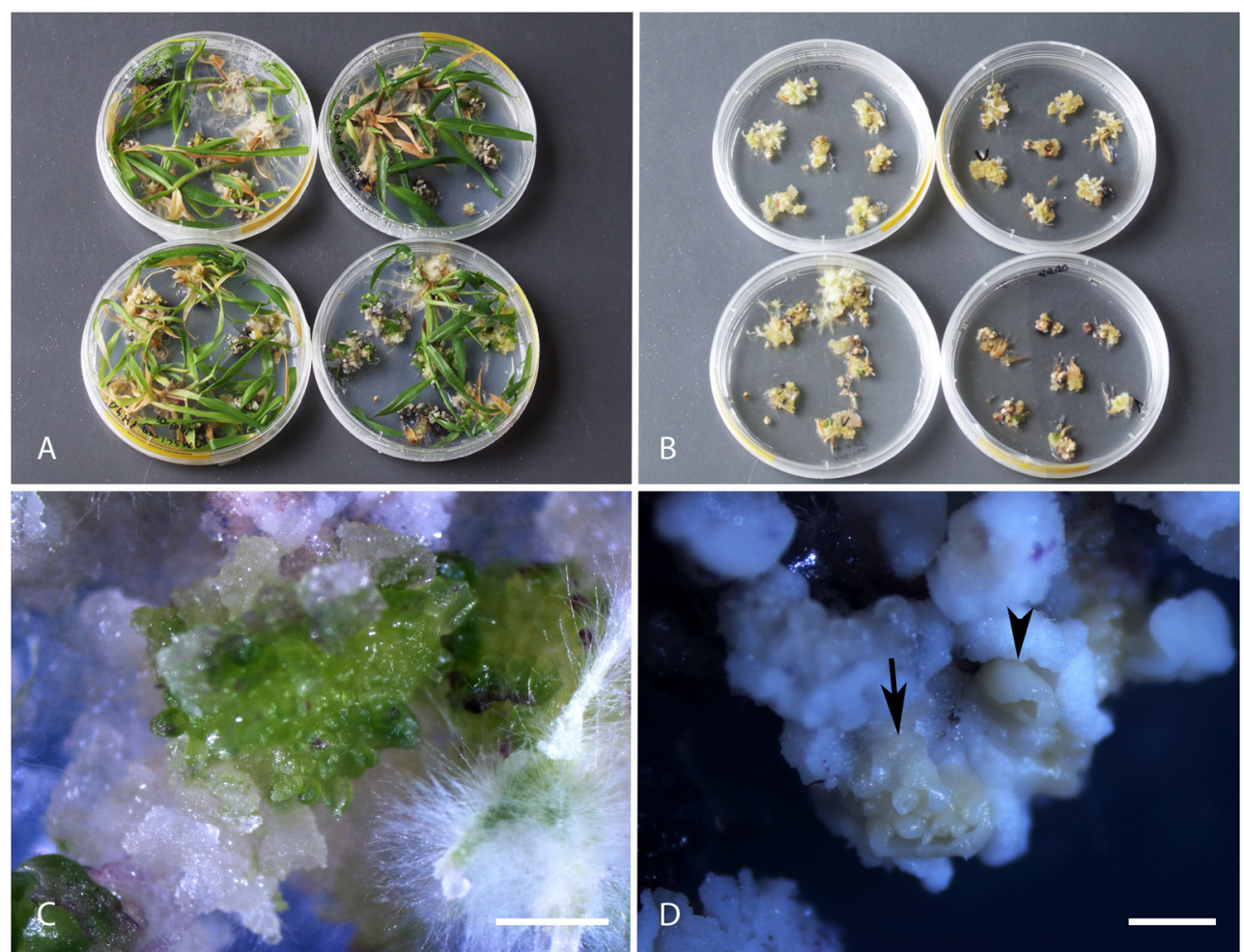

Figure 1. Morphogenetic response of Brachiaria brizantha callus derived from mature seeds, after removal of visible embryogenic callus, cultured in different regeneration media. $A$ Shoot development in MS3 medium. $B$ Root proliferation in NBreg medium. $C-D$ Calli in MS3 regeneration medium showing areas with shoot bud formation $(C)$ and

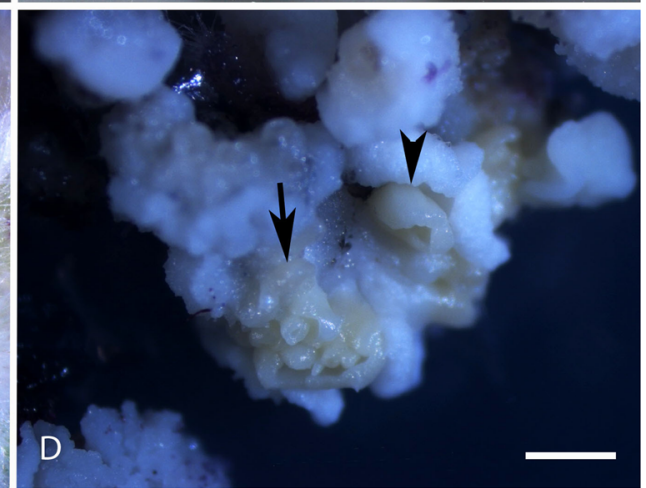
$2 \mathrm{~mm}, D 1 \mathrm{~mm}$. combination. In the composition of NBreg medium, only BAP is present $(3 \mathrm{mg} / \mathrm{L})$. Likewise, in Solanum surattense, the combination of cytokinins was more efficient for regeneration of buds and shoots than separately (Yadav et al. 2010). The development of shoots and somatic embryos from calli after removing visible embryogenic tissue indicates the unsynchronized induction in the same callus, including embryogenic structures that were not perceptible.

In $B$. brizantha, three different phases were characterized during embryogenic callus formation (Fig. 2). In the first phase, the tissue was compact, hard and round, 1 to $2 \mathrm{~mm}$ in

areas with somatic embryos in different patterns, one scutellum surrounding several embryo axes (arrow) and a well-differentiated somatic embryo with one embryo axis and its scutellum (arrowhead), showing white scutellum and cream-colored embryo axis $(D)$. Bars $C$ 

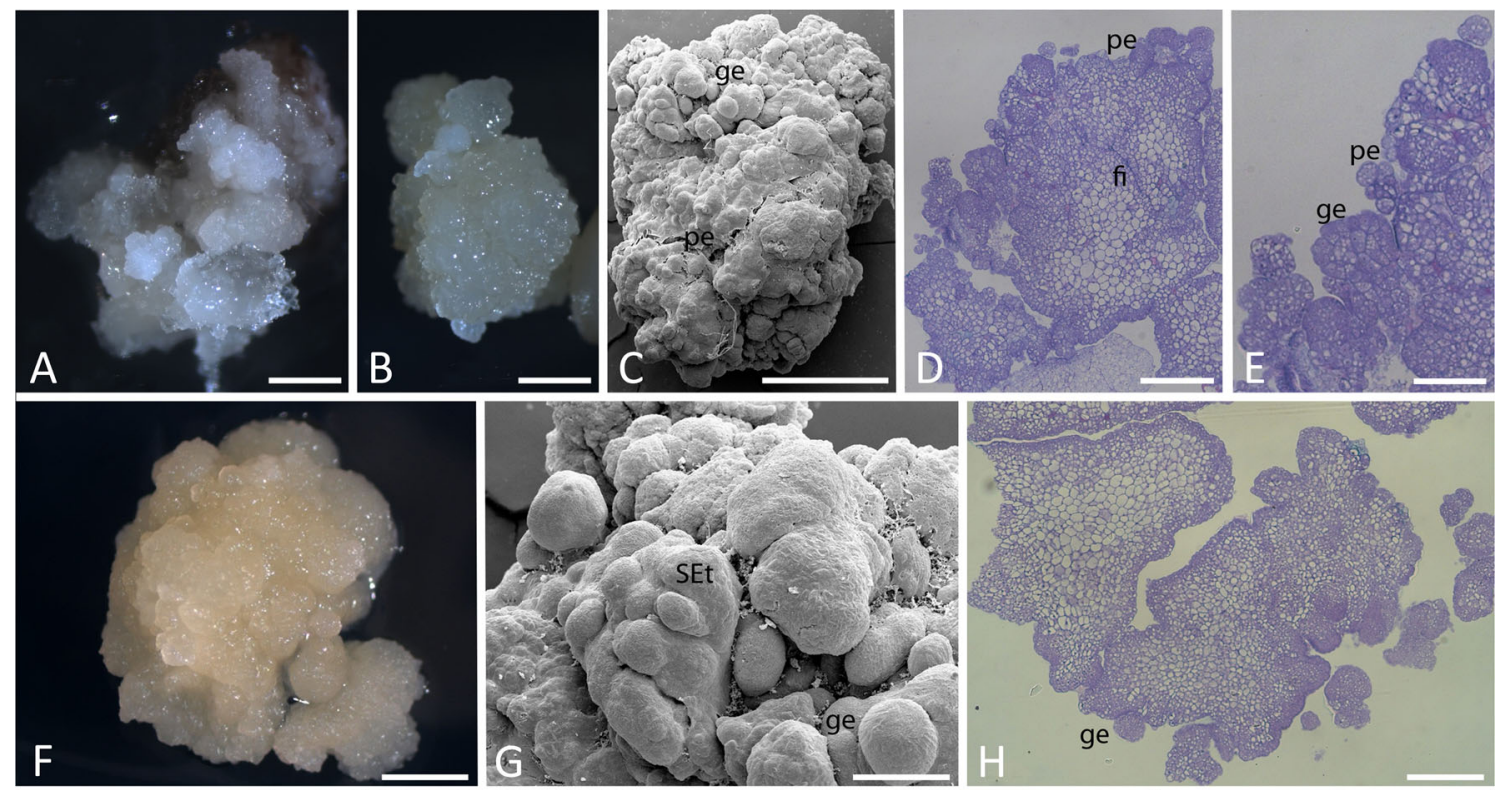
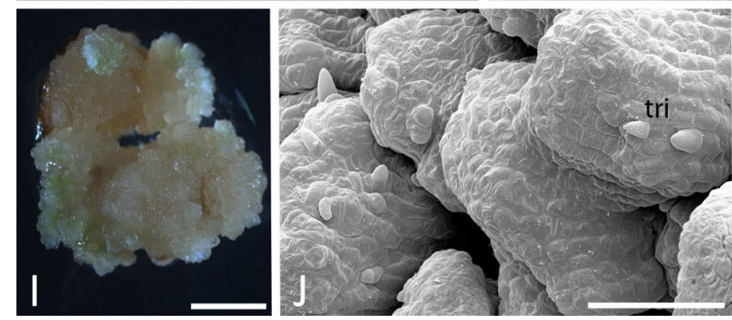

Figure 2. Development of Brachiaria brizantha embryogenic callus in M1.3/NBBAP/NBreg sequence of culture media. Micrographs obtained under the stereomicroscope $(A, B, F, I, L)$; histological sections $(D, E, H$, $K)$; and scanning electron micrographs $(C, G, J) . A-E$ Phase I showing clumps of embryogenic and non-embryogenic callus $(A)$; isolated embryogenic callus $(B)$; embryogenic callus with proembryos and globular embryos $(C)$; histological section of embryogenic callus showing proembryos and fissures frequently observed in embryogenic callus $(D)$, detail of proembryos and globular embryos from $D(E) . F-H$ In phase II, embryogenic callus with differentiating embryo axes and

diameter, and had a smooth surface (Fig. 2A, B). Intensely proliferating meristematic regions were observed, as well as proembryos and somatic embryos at the globular stage (Fig. $2 C-E$ ). In detail, it was possible to observe that the embryogenic tissue surface presented small cell clumps or small

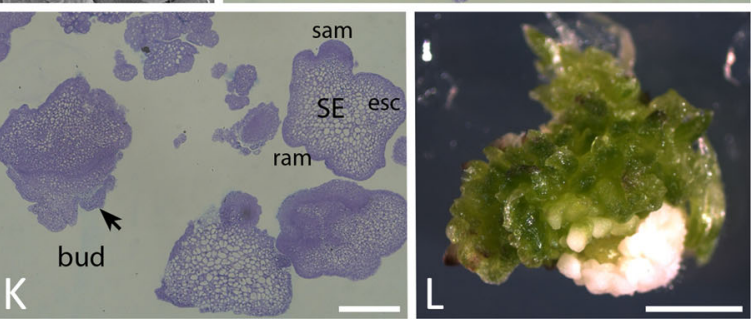

mature somatic embryos. $I-K$ Embryogenic callus in phase III, showing differentiated structures $(I)$, embryogenic callus with leafy structures and scutellum-leafy trichomes $(J)$, and somatic embryo with well-developed scutellum, with sam and ram, and shoot bud proliferation (arrow) $(K) . L$ Embryogenic tissue with green shoot buds and shoots with a whitish welldifferentiated scutellum. Bars A, B, C, F $1 \mathrm{~mm} ; D, J 100 \mu \mathrm{m} ; E 50 \mu \mathrm{m} ; G$, $H, I, K, L 200 \mu \mathrm{m}$; bud adventitious bud, sam shoot apical meristem, ram root apical meristem, esc scutellum, $f i$ fissure, ge globular embryo, pe proembryo, $S E t$ somatic embryo in torpedo stage, tri trichome.

cells with dense cytoplasm, indicating the high metabolic activity and high division cell rate (Fig. 2D, E) that characterize somatic embryogenesis-competent cells. Another characteristic observed on the surface of embryogenic tissue was the presence of fissures, indicating regions of embryo detachment,

Table 3 Effects of different induction media on the multiplication of Brachiaria brizantha embryogenic callus after $10 \mathrm{~d}$ of culture in fresh induction medium

\begin{tabular}{|c|c|c|c|c|c|}
\hline \multirow[t]{2}{*}{ Culture medium } & \multirow[t]{2}{*}{ Total } & \multicolumn{4}{|c|}{ Embryogenic callus number with (\%) } \\
\hline & & Browning callus & Friable callus & Friable callus $+\mathrm{EC}+\mathrm{DSE}$ & Friable callus + DSE \\
\hline M1.3 & 152 & $14(9) \mathrm{b}$ & $30(20) b$ & $18(12) \mathrm{c}$ & $90(59) \mathrm{a}$ \\
\hline NB & 268 & $45(17) \mathrm{a}$ & $104(39) \mathrm{a}$ & $77(29) b$ & $42(15) b$ \\
\hline NBBAP & 306 & $21(7) b$ & $52(17) b$ & $196(64) \mathrm{a}$ & $37(12) b$ \\
\hline
\end{tabular}

Each treatment was carried out with three independent replications, in which at least 50 explants were considered as one replicate. Means in a column sharing the same letter are not significantly different $(p<0.05)$

$\%$ percentage ratio, DSE differentiated somatic embryos (with visible scutellum), $E C$ embryogenic callus 
Table 4 Summary of the best conditions to obtain embryogenic callus followed by plant regeneration from Brachiaria brizantha

\begin{tabular}{llll}
\hline In vitro step & $\begin{array}{l}\text { Best culture } \\
\text { medium }\end{array}$ & $\begin{array}{l}\text { Culture } \\
\text { period }\end{array}$ & $\begin{array}{l}\text { Culture } \\
\text { conditions }\end{array}$ \\
\hline Induction & M1.3 & $30 \mathrm{~d}$ & dark \\
$\begin{array}{l}\text { Multiplication } \\
\text { Regeneration }\end{array}$ & NBBAP & $10 \mathrm{~d}$ & dark \\
\hline
\end{tabular}

M1.3 and NBBAP induction medium, NBreg regeneration medium

giving rise to other embryos. In phase II, the embryogenic tissues were less compact and more differentiated (Fig. $2 F$ ), exhibited a more rough surface, measured 3 to $4 \mathrm{~mm}$ in diameter, and contained globular and cotiledonary somatic embryos (Fig. 2G, $H$ ). In phase III, the embryos became green and possessed scutellum-like structures with trichomes (Fig. 2J). At this stage, it was common to observe different stages of embryo development and buds, a characteristic of repetitive systems (Fig. $2 K, L$ ).

The embryogenic tissue showed distinct morphogenic responses during multiplication in the different induction media (Table 3). In NBBAP medium, $64 \%$ of embryogenic tissue proliferated friable calli, plus differentiated somatic embryos (DSE), compared to only $12 \%$ on M1.3 medium. Moreover, in NBBAP medium, $12 \%$ of embryogenic tissue proliferated friable callus plus differentiated somatic embryos (DSE), compared to $59 \%$ in M1.3 medium. This indicates that, despite being a very effective medium for somatic embryogenesis induction in the mature seed scutellum of B. brizantha,
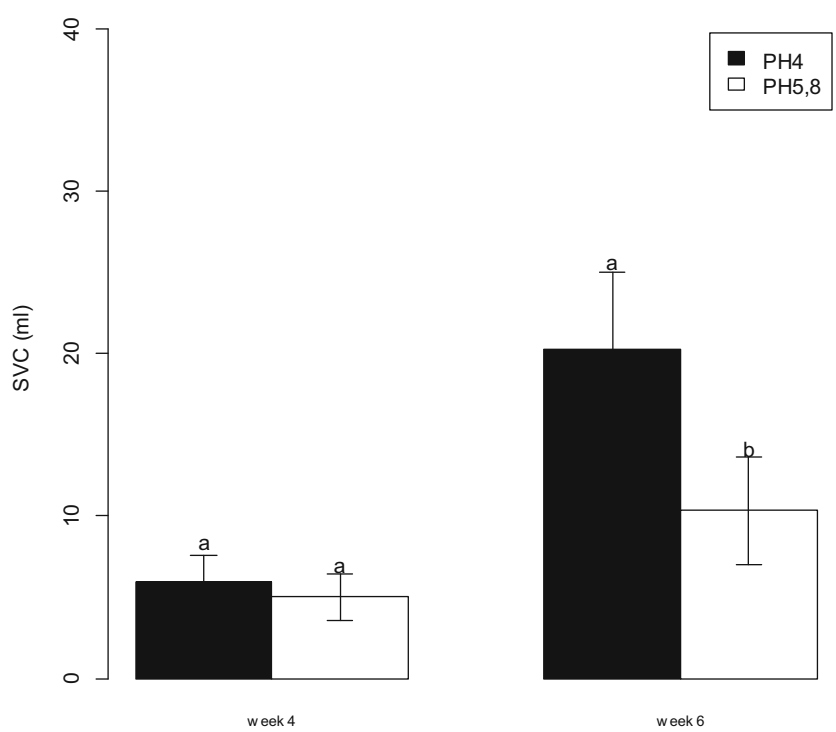

Figure 3. Effect of the $\mathrm{pH}$ of NBBAP induction medium on cell suspension proliferation, measured by the settled cell volume $(\mathrm{SCV})$ after 4 and $6 \mathrm{wk}$ of culture. Vertical bars represent the standard error of the mean ( $n=6$ flasks per treatment). Different letters indicate significant differences at $5 \%$ level of probability according to Tukey's test.
Table 5 Effect of the induction medium (M1.3 or NBBAP) in Brachiaria brizantha cell suspension proliferation measured by the settled cell volume (SCV) during $10 \mathrm{wk}$ of culture at $\mathrm{pH} 4$

\begin{tabular}{lll}
\hline Week in culture & \multicolumn{2}{l}{ Induction medium } \\
\cline { 2 - 3 } & M1.3 & NBBAP \\
\hline 4 & $4.80 \pm 1.01 \mathrm{aA}$ & $4.70 \pm 0.48 \mathrm{aA}$ \\
6 & $15.43 \pm 4.25 \mathrm{aB}$ & $6.40 \pm 2.22 \mathrm{bB}$ \\
8 & $29.40 \pm 5.44 \mathrm{aC}$ & $15.95 \pm 3.48 \mathrm{bC}$ \\
10 & $42.87 \pm 5.76 \mathrm{aD}$ & $31.50 \pm 4.96 \mathrm{bD}$
\end{tabular}

Data represent means $\pm \mathrm{SD}(n=5)$. Different lowercase letters indicate that induction medium differ significantly, while different uppercase letters indicate that time of culture differ significantly $(p<0.05)$ based on Tukey's test

NBBAP is not suitable for maintaining the meristematic state and potentially embryogenic cultures. In this medium, differentiation of somatic embryos occurs rapidly from embryogenic callus, with embryos showing scutellum differentiation (Fig. 2). In NB medium, the embryogenic tissue showed higher rates of oxidative browning (17\%) than in the other two media, M1.3 and NBBAP, with approximately $30 \%$ of calli showing potential for repetitive cultures. Our results indicate that NBBAP medium was the most appropriate for maintenance of the embryogenic/meristematic potential of the embryogenic tissue.

Independently of the induction medium, the regeneration medium NBreg favored shoot development (Fig. $2 L$, Supplemental Table 1). Likewise, the embryogenic tissues obtained

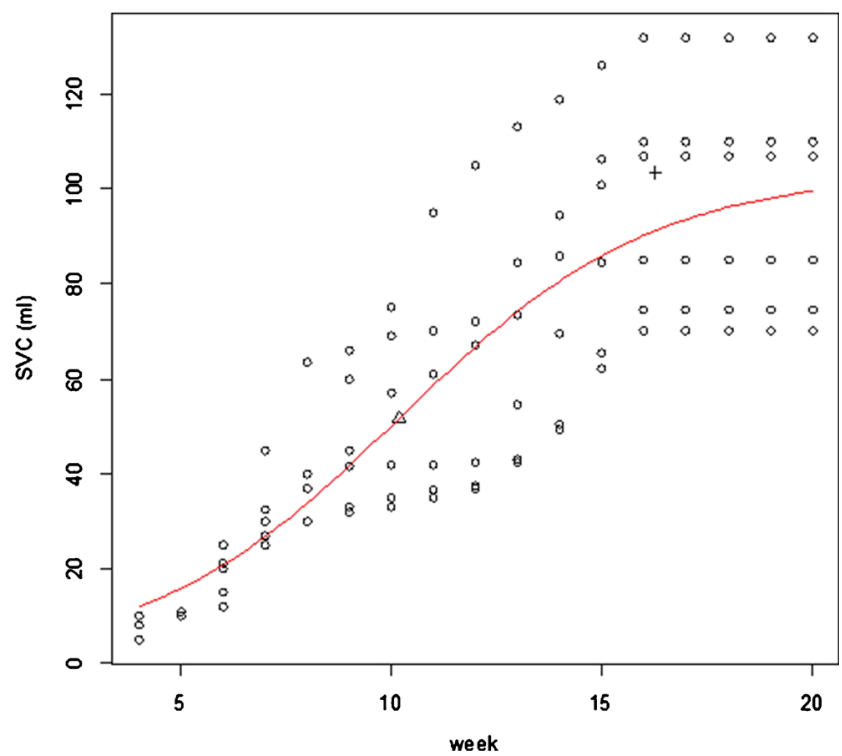

Figure 4. A cell suspension growth curve obtained by weekly subcultures in M1.3 medium in the course of $20 \mathrm{wk}$ measured by the increase of SCV (settled cell volume) and analyzed by the logistic curve. The explanatory power of the logistic curve was $72.37 \%\left(R^{2}\right) . \Delta$ inflection point; + plateau point. 
in NB medium generally showed high rates of root formation, either in NBreg (36\%), or in the pre-regeneration medium before subculture to the regeneration medium NBreg (44\%) (Supplemental Table 1). In summary, the NB induction medium did not favor embryos or shoot formation but led to root proliferation. NBreg medium favored shoot development from callus, regardless of the induction medium used, and was more effective when used directly, without a preregeneration medium (Supplemental Table 1).

Higher efficiency regeneration systems take less time (Table 4), possibly resulting in lower costs. The reduction of one culture step (pre-regeneration) can be advantageous, because of the higher chance of the occurrence of somaclonal variation with extended time in culture (Taparia et al. 2012) and also with exposure to growth regulators (Cassells and
Curry 2001). Recently, Ishigaki et al. (2014) showed that 4mo-old embryogenic callus generated polyploids, while all regenerants derived from 2-mo-old embryogenic calli were diploid, suggesting that extended times in culture can lead to duplication of chromosomes in rapidly proliferating embryogenic callus of ruzigrass (B. ruziziensis). Cabral et al. (2011) showed in B. brizantha that 4-mo-old embryogenic callus from mature seeds regenerated only albino plants. These data indicate that 2-mo-old or younger embryogenic calli are best suited for Brachiaria spp. In general, it is not difficult to induce callus from grasses (Wang et al. 2001). It is often the multiplication/maintenance of embryogenic state with further regeneration of green plants that is the challenge (Wu et al. 2014). In this study, high frequencies of embryogenic tissue induction in M1.3 medium (70\%),
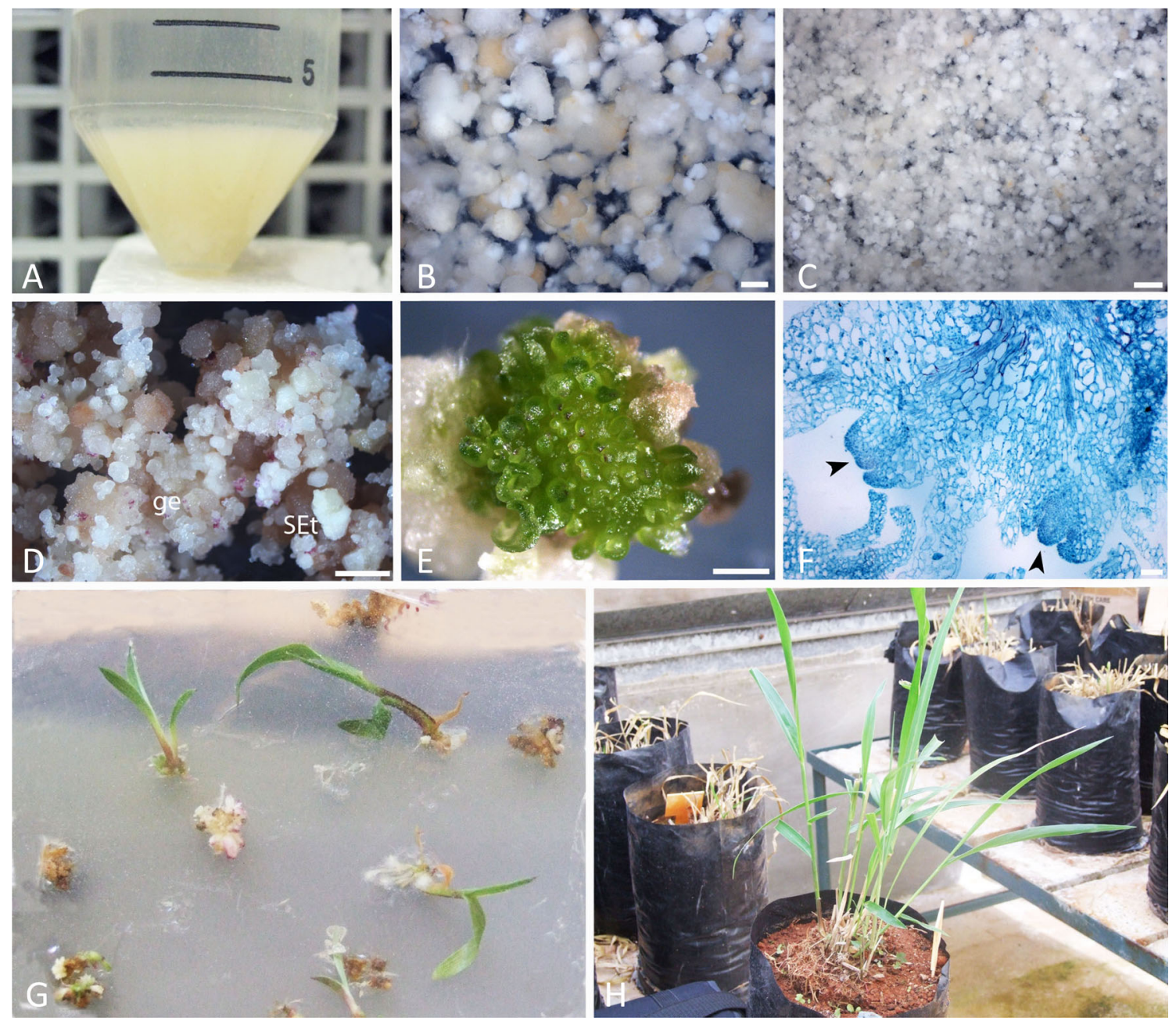

Figure 5. Induction in M1.3 or NBBAP medium and regeneration of Brachiaria brizantha embryogenic cell suspensions (CS) obtained in DD1 medium followed by NBreg solid medium covered with MS3liq to complement medium components. $A$ Cell suspension obtained after a 4-wk culture in M1.3 medium, $\mathrm{pH}$ 4. $B-C \mathrm{CS}$ after 8 wk in liquid medium M1.3, pH $4(B)$ and NBBAP, pH $4(C) . D-E$ CS in NBreg solid medium presenting SE with or without differentiated scutellum $(D)$ and with bud

proliferation $(E) . F$ Histological section of a cell aggregate presenting multiple buds showing the shoot apical meristem (arrowheads) and vascular tissue attached to the original callus. $G$ Isolated shoots from CS. $H$ plants obtained from CS in the greenhouse. ge globular embryo, $S E$ somatic embryo, M1.3 and NBBAP induction media, NBreg regeneration medium. Bars $B, C, E 1 \mathrm{~mm}, D 2 \mathrm{~mm}, F 100 \mu \mathrm{m}, G 5 \mathrm{~mm}$. 
multiplication in NBBAP medium (64\%), and plant regeneration in NBreg (up to $84 \%$ ) were achieved from 2-moold cultures.

Induction and regeneration of cell suspension. Comparisons of $\mathrm{pH}$ in the NBBAP induction medium for cell suspension cultures showed that use of media at $\mathrm{pH} 4$ resulted in a fourfold increase in settled cell volume (SCV) at $6 \mathrm{wk}(p=1.14 \mathrm{e}-$ 14) as compared to pH 5.8 (Fig. 3), which may be a result of a higher cell multiplication rate. This result, in addition to the response observed in callus (Cabral et al. 2011), indicates a positive effect of an acidic $\mathrm{pH}$ in cell proliferation in B. brizantha.

After $6 \mathrm{wk}$ in culture, the SCV was significantly higher in M1.3 than in NBBAP ( $p=2 \mathrm{e}-16$; Table 5 ). Cell suspensions obtained in different culture media (Table 5; Figs. 3, 4, and $5 A$ ) showed a similar lag phase of $4 \mathrm{wk}$ before SCV began to increase (Fig. 5A). The lag phase was the time from callus inoculation into liquid medium to the stage when a rapid increase in cell volume was observed. A CS growth curve was obtained by weekly subcultures in M1.3 medium in the course of $20 \mathrm{wk}$, and we observed that SCV increased slowly until $10 \mathrm{wk}(51.74 \mathrm{~mL}$ of SCV), followed by a faster increase in SCV and a stabilization around $16 \mathrm{wk}$ at $103.48 \mathrm{~mL}$ of SCV Fig. 4. The curve indicated an inflection point at $10 \mathrm{wk}$ and a plateau point at $16 \mathrm{wk}$ that delimited the exponential or $\log$ phase as a period of high cell division rate. The increase in SCV may also reflect the elevated cell proliferation due to the larger cell clumps observed in M1.3 medium (Fig. 5B), compared to NBBAP medium (Fig. 5C). The suspension cell clusters obtained and cultivated in M1.3 were very similar to the embryogenic tissue at phase I described earlier (Fig. 2B-E), having a high proliferative capacity with a high proportion of small, dense, yellowish, isodiametric cells, as also observed in Colocasia esculenta CS (Deo et al. 2010). Moreover, the plateau point indicated the beginning of a stationary phase, the arrest in cell multiplication that can be an effect of endogenous factors causing cell division inhibition, or cell death.

When M1.3 was used for induction, the number of shoots obtained was almost fourfold (328) higher than for NBBAP (83). Furthermore, the percentage of albino shoots was lower in M1.3 (34\%), than in NBBAP medium (69\%). After transferring CS to pre-regeneration or regeneration media, regeneration of somatic embryos, multiple buds, shoots, and roots was evident (Fig. $5 D-G$ ). In some treatments, a high percentage of albino shoots was observed. The largest number of green shoots, as well as the highest conversion of cell aggregates into somatic embryos, were obtained in CS cultured in DD1 pre-regeneration medium followed by NBreg medium (Supplemental Table 1). The efficiency of DD1 as a preregeneration medium may be due to its lower 2,4-D concentration, the use of zeatin, and consequently, a lower auxin/ cytokinin ratio, as compared to the induction media, which favors somatic embryo differentiation. Somatic embryo germination may have been enhanced in the presence of cytokinins in the regeneration medium, or culture conditions may have stimulated the bud differentiation and proliferation (Fig. $5 E, F$ ). The NB medium was initially described for rice and tested in this work for $B$. brizantha because of its content of amino acids, such as proline and glutamine. However, the original medium without BAP failed to induce regeneration in Brachiaria. NB medium supplemented with $0.2 \mathrm{mg} / \mathrm{L}$ BAP for induction resulted in regeneration of green shoots, regardless of the pre-regeneration and regeneration medium used. The proliferation of undifferentiated cells in different media combinations was higher in CS cultured in NBBAP than in M1.3 medium.

The media combination M1.3/DD1/NBreg/MS3liq was the most efficient for achieving multiplication and regeneration from CS (Fig. 5A-G). Isolated and multiple shoots, as well as embryogenic calli, were obtained from cell suspensions. Regenerated plantlets, when acclimatized in the greenhouse (Fig. $5 H$ ), showed morphological patterns of growth, flowering, and seed production that were, similar to tillerpropagated plants (data not shown).

In this study, a somatic embryogenesis system was established from embryogenic callus of $B$. brizantha $\mathrm{cv}$. Marandu, using M1.3 medium for induction, NBBAP medium for embryo multiplication, and NBreg for plant regeneration. This system was efficient for plant regeneration, and embryogenic callus in phase I showed a high cell division rate. Additionally, a methodology for induction, maintenance, and regeneration of $B$. brizantha by cell suspensions was established, using a sequence of steps in M1.3, DD1, NBreg, and MS3 media.

Acknowledgments We would like to thank Cacilda B. do Valle, Embrapa Beef Cattle, for providing seeds for the experiments. This work was supported by research funds from Embrapa and CNPq. APM acknowledges CNPq for research fellowships (PQ 305.785/2008-7).

\section{References}

Cabral GB, Carneiro VTC, Lacerda AL, Do Valle CB, Martinelli AP, Dusi DMA (2011) Somatic embryogenesis and organogenesis in apomictic and sexual Brachiaria brizantha. Plant Cell Tiss Org Cult 107:271-282

Cassells AC, Curry RF (2001) Oxidative stress and physiological, epigenetic and genetic variability in plant tissue culture: implications for micropropagators and genetic engineers. Plant Cell Tiss Org Cult 64:145-157

Deo PC, Taylor M, Harding RM, Tyagi AP, Becker DK (2010) Initiation of embryogenic cell suspensions of taro (Colocasia esculenta var. esculenta) and plant regeneration. Plant Cell Tiss Org Cult 100:283291

Do Valle CB, Savidan Y (1996) Genetics, cytogenetics, and reproductive biology of Brachiaria. In: Miles JW, Maass BL, Do Valle CB (eds) 
Brachiaria: biology, agronomy, and improvement. CIAT - Embrapa, Cali - Brasilia, pp 147-163

Felismino MF, Pagliarini MS, Do Valle CB, Resende RMS (2012) Meiotic stability in two valuable interspecific hybrids of Brachiaria (Poaceae). Plant Breed 131:402-408

Hiei Y, Komari T, Kubo T (1997) Transformation of rice mediated by Agrobacterium tumefaciens. Plant Mol Biol 35:205-218

Ishigaki G, Gondo T, Suenaga K, Akashi R (2009) Multiple shoot formation, somatic embryogenesis and plant regeneration from seedderived shoot apical meristems in ruzigrass (Brachiaria ruziziensis). J Jpn Grassl Sci 55:46-51

Ishigaki G, Gondo T, Suenaga K, Akashi R (2012) Fertile transgenic Brachiaria ruziziensis (ruzigrass) plants by particle bombardment of tetraploidized callus. J Plant Physiol 169:546-549

Ishigaki G, Gondo T, Rahman MM, Umami N, Akashi R (2014) Spontaneous appearance of polyploids in plants regenerated from embryogenic calli derived from seedling-meristems of ruzigrass (Brachiaria ruziziensis Germain et Everard). J Jpn Grassl Sci 60: 24-30

Lenis-Manzano S (1998) Desenvolvimento de um método de transformação genética de Brachiaria spp. por bombardeamento de partículas. Dissertação de Mestrado da Universidade de Brasília, Brasília, DF, p 131

Lenis-Manzano SJ, Araujo ACG, Valle CB, Santana EF, Carneiro VTC (2010) Histologia da embriogênese somática induzida em embriões de sementes maduras de Urochloa brizantha apomítica. Pesq Agrop Brasileira 45:435-441

Matsumoto K (2006) Cultura de células em suspensão - focalizando a bananeira. Bol Pesq Desenv Embrapa Brasília DF 126:1-21

Murashige T, Skoog F (1962) A revised medium for rapid growth and bio assays with tobacco tissue cultures. Physiol Plant 15:473-497

Pinheiro AA, Pozzobon MT, Do Valle CB, Penteado MIO, Carneiro VTC (2000) Duplication of the chromosome number of diploid Brachiaria brizantha plants using colchicine. Plant Cell Rep 19: 274-278

R Core Team (2013) R: A language and environment for statistical computing. R Foundation for Statistical Computing, Vienna, Austria. http://www.R-project.org/. Cited 4 April 2014
Sallaud C, Meunard D, Van Boxtel J, Gay C, Bès M, Brizard JP, Larmande P, Ortega D, Raynal M, Portefaix M, Ouwerkerk PBF, Rueb S, Delseny M, Guiderdoni E (2003) Highly efficient production and characterization of T-DNA plants for rice (Oryza sativa L.) functional genomics. Theor Appl Genet 106:1396-1408

Silveira ED, Rodrigues JCM, Cabral GB, Leite JA, Costa SS, Carneiro VTC (2003) Evaluation of exogenous promoters for use in Brachiaria brizantha transformation. J Plant Biotechnol 5:87-93

Taparia Y, Gallo M, Altpeter F (2012) Comparison of direct and indirect embryogenesis protocols, biolistic gene transfer and selection parameters for efficient genetic transformation of sugarcane. Plant Cell Tiss Org Cult 111:131-141

Tohme J, Palacios N, Lenis S, Roca W (1996) Applications of biotechnology to Brachiaria. In: Miles JW, Maass BL, Do Valle CB (eds) Brachiaria: biology, agronomy, and improvement. CIAT - Embrapa, Cali - Brasilia, pp 196-204

Vasil IK (2005) The story of transgenic cereals: the challenge, the debate, and the solution - a historical perspective. In Vitro Cell Dev Biol Plant 41:577-583

Vasil V, Vasil IK (1980) Isolation and culture of cereal protoplasts. Theor Appl Genet 56:97-99

Vasil V, Vasil IK (1982) Characterization of an embryogenic cell suspension culture derived from cultured inflorescences of Pennisetum americanum (Pearl millet, Gramineae). Amer J Bot 69:1441-1449

Wang ZY, Hopkins A, Mian R (2001) Forage and turf grass biotechnology. Crit Rev Plant Sci 20:573-619

Wang W, Zhao X, Zhuang G, Wang S, Chen F (2008) Simple hormonal regulation of somatic embryogenesis and/or shoot organogenesis in caryopsis cultures of Pogonatherum paniceum (Poaceae). Plant Cell Tiss Org Cult 95:57-67

Wu E, Lenderts B, Glassman K, Berezowska-Kaniewska M, Christensen H, Asmus T, Zhen S, Chu U, Cho M-J, Zhao Z-Y (2014) Optimized Agrobacterium-mediated sorghum transformation protocol and molecular data of transgenic sorghum plants. In Vitro Cell Dev Biol Plant 50:9-18

Yadav SK, Kachhwaha S, Kothari SL (2010) Comparison of in vitro regeneration efficiency of leaf explants in response to different cytokinins and assessment of genetic uniformity of regenerated plants of Solanum surattense Burm.f. Afric J Biotechnol 9:8991-8997 